\title{
Physical and Chemical Characteristics of Depigmented Oven Dried Dehulled Millet Flours
}

\author{
Eunice Asheobin Adgidzi ${ }^{1,2}$, Jane Chinyelu Ani ${ }^{2}$, Roselina Karim ${ }^{1}$, Hasanah Mohd Ghazali ${ }^{1}$
}

${ }^{I}$ Faculty of Food Science and Technology, Universiti Putra Malaysia. ${ }^{2}$ Department of Food Science and Technology. University of Nigeria, Nsukka. A R T I C LE IN F O

\section{Research Article}

Received 19 March 2018 Accepted 18 June 2018

Keywords:

Depigmented

Oven dried

Dehulled millet

Flour

Soak solution

*Corresponding Author:

E-mail: euniceadgidzia@gmail.com \begin{abstract}
A B S T R A C T
The physical and chemical characteristics oven dried millet flour from dehulled millet soaked in different media was studied. Depigmented oven dried dehulled millet flour was produced by soaking dehulled millet in different solutions; water, $1 \% \mathrm{NaCl}, 1 \% \mathrm{Na}_{2} \mathrm{CO}_{3}$, and $1 \%$ citric acid. All samples were soaked in their respective solution for $12 \mathrm{~h}$, dried in the oven at $60^{\circ} \mathrm{C}$ for $6 \mathrm{~h}$ then milled into flour and sieved through $710 \mu \mathrm{m}$ mesh size. The physical properties of oven dried dehulled millet; colour had $\mathrm{L}^{*}$ (whiteness value), a* (redness values), and $\mathrm{b}^{*}$ (yellowness values) that differed significantly ranging from 66.74 to $84.21,0.85$ to 1.43 , and 6.89 to 12.69 respectively. The minimum, mean and maximum particle size distributions of samples ranged from 9.53 to $23.41 \mu \mathrm{m}, 29.09$ to $50.15 \mu \mathrm{m}$ and 59.46 to $176.01 \mu \mathrm{m}$ respectively. Starch granules in micrographs of oven dried depigmented millet flours were irregular, compact and polygonally shaped. Gelatinization properties of oven dried millet flour; the onset temperature (To), peak temperature (Tp), end set temperature (Te) and enthalpy varied significantly ranging from 70.15 to $97.65^{\circ} \mathrm{C}, 79.48$ to $102.31^{\circ} \mathrm{C}, 83.30$ to $104.96^{\circ} \mathrm{C}$, and 6.70 to $28.41(\mathrm{~J} / \mathrm{g})$ respectively. Chemical properties comprising of moisture, fats, ash, protein, crude fiber, $\mathrm{pH}$, total titratable acidity, $\mathrm{pH}$ of soak solution, phytates and tannins varied significantly ranging from 10.19 to $10.88 \%, 4.27$ to $4.61 \%, 0.71$ to $1.19 \%, 7.25$ to $8.67 \%, 1.00$ to $1.08 \%, 4.35$ to $8.45,0.001$ to $0.084 \%, 3.32$ to $9.93,0.60$ to $0.62,1.84$ to $6.45 \mathrm{mg} / \mathrm{g}$ and 3.06 to $6.68 \mathrm{mg} / \mathrm{g}$ respectively. Depigmenting dehulled millet by soaking in $1 \% \mathrm{Na}_{2} \mathrm{CO}_{3}$ impaired the colour of sample ODMF2 while depigmenting dehulled millet grains by soaking in $1 \%$ citric acid solution for $12 \mathrm{~h}$ improved colour of sample ODMF1.
\end{abstract}

DOI: https://doi.org/10.24925/turjaf.v6i8.1022-1029.1924

\section{Introduction}

Millet is regarded as an under-utilized cereal, because of its minimal inclusion in commercial food systems, lack of research and novel product development processes even in agro-ecological systems where grown (Shahidi and Chandrasekar, 2013). Hence, millet is often referred to as coarse grain cereal and poor man's crop due to its use by economically disadvantaged population in Asian and African countries. Millet is a drought, disease and pest resistant crop (Saleh et al., 2013), thus it can be considered as a suitable adaptable crop to mitigate the effect climate change especially in areas where conditions have become desert-like, thereby conferring it a leading role in food security. Millet has a good nutritional profile of either superiority or comparison to rice, maize and sorghum in terms of energy density, protein, fat, minerals and vitamins, yet it has remained a food for low socioeconomic groups due to the presence of pigments in the pericarp and endosperm layers, giving the millet products an undesirable color and taste. The seed coat normally imparts dark colour, chewy texture and characteristic musty odour to the food products and these largely hinder their acceptability by the non- traditional millet consumers (Shobana and Malleshi, 2007). The increased use of millet is dependent on the removal of these pigments. Nigeria produces about 5.0 million tonnes of millet annually and had evolved a traditional method of acidifying millet with lime or tamarind juice. Acidification of millet with lime or tamarind juice improved the colour and taste of millet based foods (Nkama and Malleshi, 1998). The coloration of pearl millet is highly correlated with the phenolics inherent in the grain, however, acidification with $\mathrm{HCl}$ showed effective reduction of the phenolic content (Reichert, 1979). Anti-nutritional factors of millet, namely phytates, tannins and polyphenols are mainly concentrated in the seed coat and aleurone layers. Different procedures have been used to reduce anti-nutritional factors of grains, namely; soaking, dehulling and application of heat which 
in turn effectively improves the nutritional value of grains. The cooking quality and protein digestibility of horse gram (Dolichos biflorus) were shown to improve by pre-soaking treatment with salt solution, $1.5 \% \mathrm{NaHCO}_{3}$ and $0.75 \%$ citric acid for $12 \mathrm{~h}$ (Kadam and Salunkhe, 1989). In view of the foregoing, there is paucity of information on the use of water and different solutions (1\%) of citric acid, $\mathrm{Na}_{2} \mathrm{CO}_{3}$ and $\mathrm{NaCl}$ as alternatives for the depigmentation of millet. The specific objective of the study was to produce flours from depigmented oven dried millet and evaluate the physical and chemical properties of the flour. It is envisaged that, increased utilization will lead to improving and standardizing the processing of millet not only at household levels but provide an opportunity at industrial level.

\section{Materials and Methods}

\section{Materials}

Millet (Pennisetum glaucum) was purchased from Alamis market, Lafia in Nasarawa State - Nigeria.

Sample preparation: Dehulled millet was processed using the modified traditional method as shown in Fig.1. Dehulled millet was depigmented by soaking in solutions (1\%) of citric acid, $\mathrm{Na}_{2} \mathrm{CO}_{3}, \mathrm{NaCl}$ and water. Oven dried millet flours were produced from dehulled depigmented dried grain.

Preparation of depigmented oven dried millet flour: Depigmented oven dried millet flour was produced from dehulled millet grains. Dehulled millet grains were cleaned, divided into eight (5) portions of $200 \mathrm{~g}$ each and soaked for $12 \mathrm{~h}$ in distilled water and $1 \%$ solutions of citric acid, $\mathrm{Na}_{2} \mathrm{CO}_{3}$ and $\mathrm{NaCl}$, respectively to effect depigmentation. The 5th portion served as control no soaking). Production of depigmented oven dried millet flour is as shown in Fig. 2.

\section{Physical Analyses}

Colour: The colour of depigmented oven dried millet flours was measured using HunterLab Colorimeter (UltraScan PRO, USA). Samples were put into an optically transparent glass cell, CIELAB value readings were taken. The ' $\mathrm{L}^{*}$ ' is a measure of whiteness (lightness) ranging from 0 (black) to (100) white, the ' $a$ *' value ranges from maximum (redness) to minimum (greenness) and the ' $b$ *' value ranges from maximum (yellowness) to minimum (blueness).

Water activity: Water activity of oven dried millet flours was measured using a water activity analyser, (Aqualab Model Series 3TE 08038569B Decagon Devices Inc. Pullman, Washington).

Particle size analysis: Particle size of depigmented oven dried millet flours was determined using a laser particle size analyzer (Mastersizer 2000, Malvern Instrument LTD, Malvern UK). Samples were fed into the mastersizer at a vibration feed rate of $50 \%$ and a dispersive air pressure of $1.475 \mathrm{bar}$. Particle sizes were classified into average minimum, mean and maximum particle sizes $(\mu m)$ by an in-built software, Scirocco 2000.

Scanning Electron Microscopy (SEM): Depigmented oven dried millet flours were analysed by scanning electron microscopy for microstructure evaluation. Samples were fixed on aluminium stubs using double sided tape and coated with a layer of gold using the sputter coater to improve conductivity. The coated samples were viewed under a scanning electron microscope (JOEL, made in Japan) using an electron voltage of 15-22v during the scan (Pellisari et al., 2012).

Differential Scanning Calorimetry: The gelatinization properties of ODMF were studied using a differential scanning calorimeter (DSC), (Mettler Toledo, Switzerland, UK) equipped with an in-built thermal analysis software, STAR ${ }^{\mathrm{e}}$. Sample $(3 \mathrm{mg})$ was loaded into a $40 \mu 1$ capacity aluminium pan with lid (Mettler, ME26763) and distilled water was added by Hamilton microsyringe, to achieve a flour water suspension containing $70 \%$ water. Samples were hermetically sealed and allowed to stand for $1 \mathrm{~h}$ at room temp before heating in the DSC. The DSC analyser was calibrated using indium and an empty aluminium pan was used as a reference. Sample pans were heated at a rate of $10^{\circ} \mathrm{C} / \mathrm{min}$ from 30 to $120^{\circ} \mathrm{C}$. The gelatinization properties of millet flour were defined as To (Onset gelatinization temperature), Tp (Peak gelatinization temperature), Te (end set gelatinization temperature), and $\Delta \mathrm{H}$ (enthalpy of gelatinization). These were calculated automatically with the in-built software, STAR ${ }^{\mathrm{e}}$.

\section{Chemical Analyses}

Proximate composition: Ash, crude protein, ether extract, crude fiber and moisture content were determined by the methods of AOAC, (2012).

Tannin: Tannin was determined by the method described by Pearson, (1976). One gram of sample was dispersed in $50 \mathrm{ml}$ of $70 \%$ acetone, placed in an ice bag and allowed to stand for $30 \mathrm{~min}$ at room temperature, and centrifuged to obtain the tannin extract. Folin- Ciocalteu reagent $(1 \mathrm{ml})$ was measured into each flask containing $10 \mathrm{ml}$ of extract, followed by $2.5 \mathrm{ml}$ of $20 \% \quad \mathrm{Na}_{2} \mathrm{CO}_{3}$ solution, the mixture was made up to mark in a $50 \mathrm{ml}$ flask and incubated for $90 \mathrm{~min}$ at room temperature. The absorbance was measured at $720 \mathrm{~nm}$ in a spectrophotometer (Genway model 6000). Tannin solution was prepared and the absorbance read at $720 \mathrm{~nm}$. The values were used to prepare the tannin standard curve a series of standard solutions $(2-10 \mu \mathrm{g} / \mathrm{ml})$. The concentration of tannin was calculated from standard curve. Readings were taken with the reagent blank at zero. Tannin content was calculated with the expression;

$$
\% \text { Tannins }=\frac{A n}{A s} \times C \times \frac{100}{w} \times \frac{V f}{V a}
$$

Where:

An = Absorbance of test material

As = Absorbance of standard solution

$\mathrm{C}=$ Concentration of standard solution

$\mathrm{W}=$ Weight of sample

$\mathrm{Vf}=$ Total volume of extract

$\mathrm{Va}=$ Volume of extract analysed

Phytates: Phytate was determined by the method of Latta and Eskin, (1980) as modified by Vaintraub and Lapteva (1988). One gram of sample was extracted with $50 \mathrm{ml}$ of $2.4 \% \mathrm{HCl}$ for $1 \mathrm{~h}$ at ambient temperature and centrifuged at $3000 \mathrm{rpm}$ for $30 \mathrm{~min}$. The clear supernatant was used for the phytate estimation, $1 \mathrm{ml}$ of Wade reagent (0.03\% $\mathrm{FeCl}_{2} .6 \mathrm{H}_{2} \mathrm{O}$ and $0.3 \%$ Sulphosalicylic acid) was 
added to $3 \mathrm{ml}$ of sample solution and centrifuged. The absorbance of the supernatant was measured at $500 \mathrm{~nm}$ using a spectrophotometer. The standard curve was prepared using absorbance values of working standard solutions of $5-40 \mathrm{mg} / \mathrm{ml}$ concentrations. The absorbance of Wade reagent not bound by phytic acid was read as the blank. The amount of phytic acid extracted from sample was calculated by subtracting from the absorbance of the blank. The difference was compared with the absorbance readings of the standard solutions, which corresponds with the various concentrations of phytic acid and expressed as phytic acid in $\mathrm{mg} / 100 \mathrm{~g}$.

$p H: \mathrm{pH}$ of a $10 \%(\mathrm{w} / \mathrm{v})$ dispersion of the samples in distilled water was read with a hand held $\mathrm{pH}$ meter (E. Merck model). Each dispersion was mixed thoroughly before the $\mathrm{pH}$ was read.

Total titratable acidity: Total titratable acidity (TTA) was determined by the method of Nielsen (2002). Ten grammes of sample was added to $100 \mathrm{ml}$ of distilled water, stirred and allowed to stand for $10 \mathrm{~min}$. Phenolphthalein indicator (3 drops) was added to $10 \mathrm{ml}$ suspension of the mixture and swirled gently. This was titrated against $0.1 \mathrm{M} \mathrm{NaOH}$ until there was a colour change from colourless to pale pink.

TTA was calculated and expressed as \% lactic acid with the expression,

$$
\% \text { Lactic acid }=\frac{\text { Volume of } \mathrm{NaOH}(\mathrm{ml})}{\text { Volume of Sample }(\mathrm{ml})} \times 0.9
$$

Iron, Iodine and Zinc: Iron, iodine, and zinc were determined by the method documented by Onwuka, (2005). Five grams of each sample was placed in a crucible for ashing in a muffle furnace at $550^{\circ} \mathrm{C}$ for $6 \mathrm{~h}$, after which it was allowed to cool for $1 \mathrm{~h}$ in the furnace before being transferred to the dessicator. Two grams of ash sample was weighed in a conical flask and $20 \mathrm{ml}$ of acid mixture $\left(650 \mathrm{ml}\right.$ Conc. $\mathrm{HNO}_{3}, 80 \mathrm{ml}$ Perchloric acid and $20 \mathrm{ml}$ Conc. $\mathrm{H}_{2} \mathrm{SO}_{4}$ ) was added. The conical flask was heated until a clear digest was obtained. The digest was diluted with distilled water to $500 \mathrm{ml}$ mark. Ten millilitres of the diluted digest was injected into the atomic absorption spectrophotometer and the absorbance was read at the wavelength $\left(\lambda_{\max }\right)$ of absorption of the respective element. Standard curves were plotted, from which the concentration of each mineral (Iodine, Iron and Zinc) was extrapolated.

Preparation of standard curves for minerals: The working standard solutions $(0.2-2.0 \mu \mathrm{g} / \mathrm{ml})$ for each mineral were prepared from the respective stock solutions. Absorbance of each standard solution was read at the maximum wavelength ( $\mathrm{Zn}$ at $213.9 \mathrm{~nm}, \mathrm{Fe}$ at $248.3 \mathrm{~nm}$ and $\mathrm{I}$ at $539.5 \mathrm{~nm}$ ) of absorptions of each mineral used to plot the standard curve. The respective mineral concentration was obtained by extrapolation from the standard curve.

\section{Experimental Design}

The experimental design was Completely Randomized Design (CRD). The data generated from the study was subjected to analysis of variance (ANOVA) using the statistical software IBM SPSS version 20. Means were separated using Duncan Multiple Range Test (DMRT) and significance was accepted at $\mathrm{P}<0.05$.

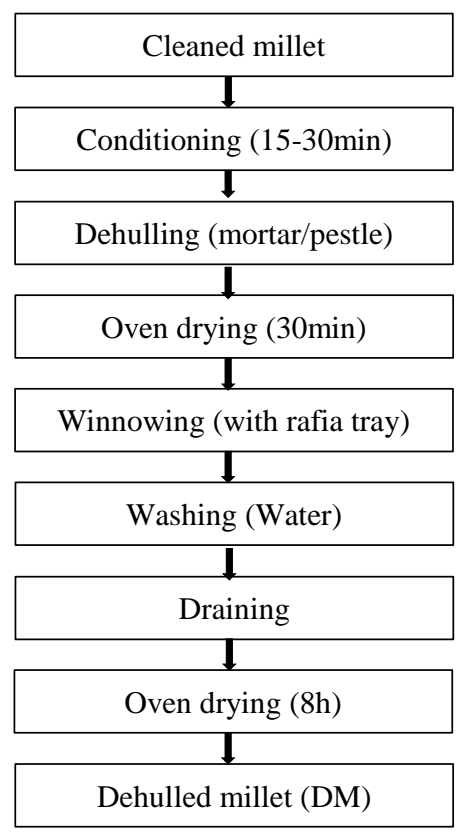

Fig.1 Flow chart for the modified traditional production of dehulled millet

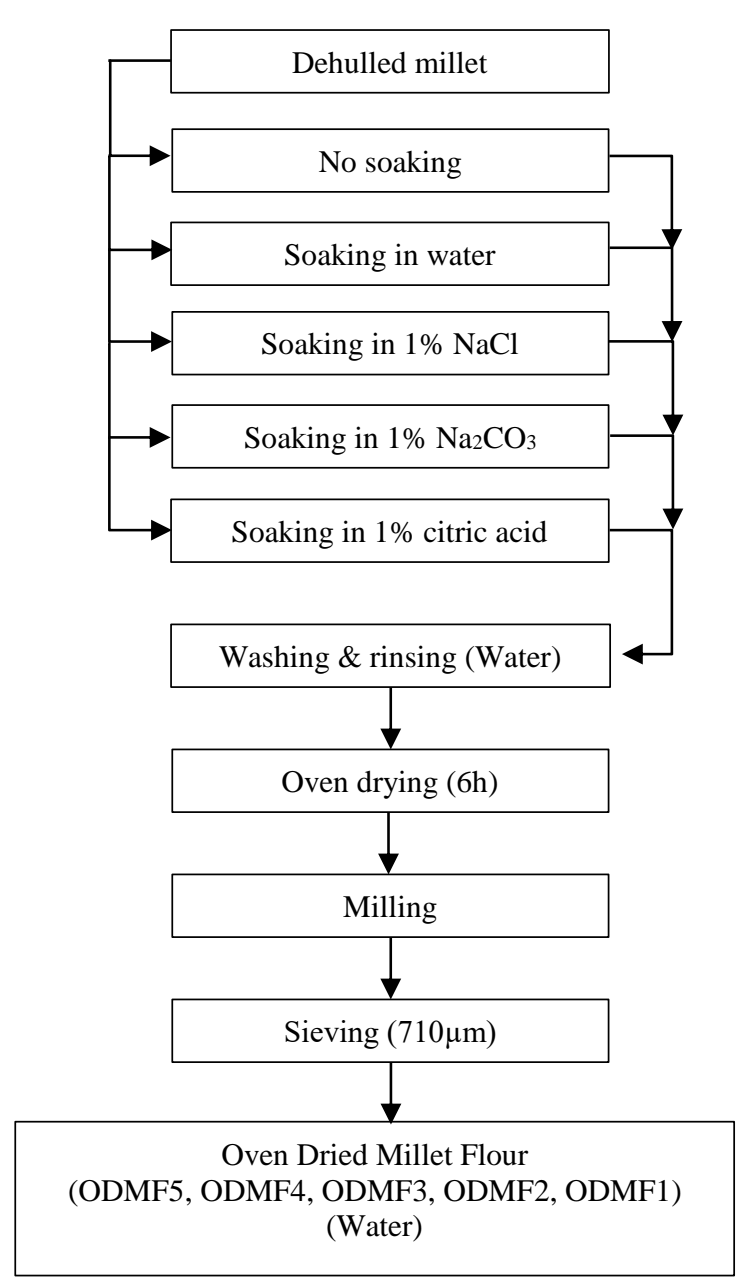

Fig. 2 Flow chart for the production of depigmented oven dried millet flours 
Legend:

ODMF1 - oven dried millet flour from dehulled millet depigmented in $1 \%$ citric acid

ODMF2 - oven dried millet flour from dehulled millet depigmented in $1 \% \mathrm{Na}_{2} \mathrm{CO} 3$

ODMF3 - oven dried millet flour from dehulled millet depigmented in $\% \mathrm{NaCl}$

ODMF4 - oven dried millet flour from dehulled millet depigmented in water

ODMF5 - oven dried millet flour from undepigmented dehulled millet (control)

\section{Results and Discussion}

\section{Physical Properties of Depigmented Oven Dried Milllet Flour}

Physical properties of depigmented oven dried millet flour is shown in Table 1. The $\mathrm{L}^{*}$ (66.74), $\mathrm{a}^{*}(0.69)$ and $b^{*}$ (6.89) values of the undepigmented sample (control) differed significantly from that of depigmented samples which ranged from 70.86 (ODMF2) to 84.21 (ODMF1), 0.85 (ODMF4) to 1.43 (ODMF2) and 8.91 (ODMF3) to 12.69 (ODMF2), respectively.

Higher $\mathrm{L}^{*}$ (whiteness) value was observed in oven dried millet flour from dehulled millet soaked in $1 \%$ citric acid solution followed by oven dried millet flour from dehulled millet soaked in $1 \% \mathrm{NaCl}$ and water. A similar trend was observed in redness value $\left(\mathrm{a}^{*}\right)$, however for yellowness value $\left(b^{*}\right)$, samples from dehulled millet soaked in $1 \%$ citric acid and $1 \% \mathrm{Na}_{2} \mathrm{CO}_{3}$ solutions had higher values. The lower $\mathrm{L}^{*}$ value (whiteness) observed in millet soaked in $1 \% \mathrm{Na}_{2} \mathrm{CO}_{3}$ solution was attributed to the polymerization of carbohydrates and proteins which led to the formation of compounds that were readily oxidizable at high $\mathrm{pH}$ to form dark coloured compounds. The observed higher whiteness value in sample ODMFI may be associated with the anti-oxidative effect of citric acid, which may have caused the whitening effect on the millet samples. Similar observations were made on mucuna beans soaked in citric acid solution while those soaked in alkali solution turned dark (Wanjekeche et al., 2003).

Soaking of dehulled millet to effect depigmentation is necessitated by consumers' preference for bright coloured millet products which is achieved by removal of the pigments. Suma and Urooj (2011) reported that flour prepared from undepigmented millet is coarse, greyish coloured and bitter tasting. These characteristics limit the utilization of millets to few traditional applications. Reichert (1979), reported that the coloration of pearl millet is highly correlated with phenolics inherent in the grain. Rathi et al. (2004) reported that pigments present in the pericarp and peripheral endosperm layers of pearl millet give the products undesirable colour and taste, consequently diversifying the use of pearl millet requires removal of these inherent pigments.

The minimum, mean and maximum particle size distribution of samples ranged from 9.53 (ODMF3) to $24.41 \mu \mathrm{m}$ (ODMF4), 29.09 (ODMF2) to $50.15 \mu \mathrm{m}$ (ODMF1) and 46.61 (ODMF2) to $176.01 \mu \mathrm{m}$ (ODMF1), respectively. Pelissari et al. (2012) made similar observation for banana flour, which exhibited a mean particle size distribution of $31.7 \mu \mathrm{m}$. The minimum particle sizes of depigmented oven dried millet flours (ODMF) indicates that $10 \%$ of the flour particle sizes are less than or smaller than the diameter within the range, $9.53-24.14 \mu \mathrm{m}$. The mean particle sizes imply $50 \%$ are less than $29.09-50.15 \mu \mathrm{m}$ and $50 \%$ is greater than 29.09 $50.15 \mu \mathrm{m}$ while the maximum sizes imply $10 \%$ of ODMF have particle sizes greater than $46.61-176.01 \mu \mathrm{m}$.

The water activity (aw) of the control sample was 0.62 while that of depigmented samples ranged from 0.60 to 0.61 . There were no significant differences $(\mathrm{P}>0.05)$ in water activity among depigmented samples, highest aw was observed in samples soaked in $1 \%$ citric acid (ODMF1) (0.61), 1\% $\mathrm{Na}_{2} \mathrm{CO}_{3}$ (ODMF2) (0.61) and $1 \%$ $\mathrm{NaCl}$ (ODMF3) (0.61) while ODMF4 had lowest aw (0.60).

Table 1 Effect of depigmentation treatments on selected physical properties of oven dried millet flour

\begin{tabular}{|c|c|c|c|c|c|c|c|}
\hline \multirow{2}{*}{ Samples } & \multicolumn{3}{|c|}{ Colour } & \multicolumn{3}{|c|}{ Particle size distribution $(\mu \mathrm{m})$} & \multirow{2}{*}{ Water activity (aw) } \\
\hline & $\mathrm{L}^{*}$ & $a^{*}$ & $\mathrm{~b}^{*}$ & Minimum & Mean & Maximum & \\
\hline ODMF1 & $84.21^{\mathrm{a}} \pm 0.21$ & $1.38^{\mathrm{bc}} \pm 0.00$ & $11.37^{\mathrm{b}} \pm 0.01$ & 17.04 & 50.15 & 176.01 & $0.61^{\mathrm{a}} \pm 0.00$ \\
\hline ODMF2 & $70.86^{c} \pm 0.17$ & $1.43^{\mathrm{ab}} \pm 0.05$ & $12.69^{\mathrm{a}} \pm 0.29$ & 14.74 & 29.09 & 46.61 & $0.61^{\mathrm{a}} \pm 0.00$ \\
\hline ODMF3 & $75.72^{b} \pm 0.24$ & $0.97^{\mathrm{e}} \pm 0.04$ & $8.91^{\mathrm{e}} \pm 0.04$ & 9.53 & 34.47 & 93.75 & $0.61^{\mathrm{a}} \pm 0.00$ \\
\hline ODMF4 & $76.45^{b} \pm 0.02$ & $0.85^{\mathrm{f}} \pm 0.01$ & $9.63^{\mathrm{d}} \pm 0.03$ & 23.41 & 45.84 & 79.29 & $0.60^{\mathrm{a}} \pm 0.00$ \\
\hline ODMF5 & $66.74^{\mathrm{d}} \pm 0.08$ & $0.69^{\mathrm{g}} \pm 0.03$ & $6.89^{f} \pm 0.09$ & 14.13 & 31.92 & 59.46 & $0.62^{\mathrm{a}} \pm 0.00$ \\
\hline
\end{tabular}

Values are means of triplicate determination \pm standard error mean (SEM). Means bearing the same superscript in the same column are not significantly different $(\mathrm{P}>0.05)$

Morphology of Starch Granules of Oven Dried Millet Flour from Different Depigmentation Treatments

Scanning electron photomicrographs of starch granules of differently treated millet flour samples is shown in Plates 1 to 5. The codes X, L, E, F, J and R in plates $1,2,3,4$ and 5 , respectively show ungelatinized starch granules that are distinctive, interlocking and compact. The photomicrographs show that the integrity of the starch granules remained intact suggesting that oven drying treatment did not affect the starch granules in the samples. The morphological features of the starch granules in all the treatment samples were found to be irregular, compact and polygonally-shaped. The observed features confirm the earlier report of Adebowale et al. (2005) that starch granule population of finger millet cluster to form an aggregated mass comprising of several small granules. Shobana and Malleshi, (2007) also reported that the endosperm of decorticated finger millet is a homogenous mass of starch granules. Apparently drying of samples at $60^{\circ} \mathrm{C}$ were not strong enough treatments to cause gelatinization hence the starch granules remained intact with no obvious morphological changes. Okafor et al. (2009) reported that transversely cut cowpea blanched in $0.5 \%$ citric acid solution viewed 
through scanning electron microscope showed a closely knit mat-like arrangement of cells, which is indicative of structural rearrangement and modification of cowpea cells by citric acid. This is in agreement with the granule arrangement of depigmented dehulled millet soaked in $1 \%$ citric acid solution (Plate 1 ) that showed a closely knit mat-like arrangement with slightly disintegrated cells.

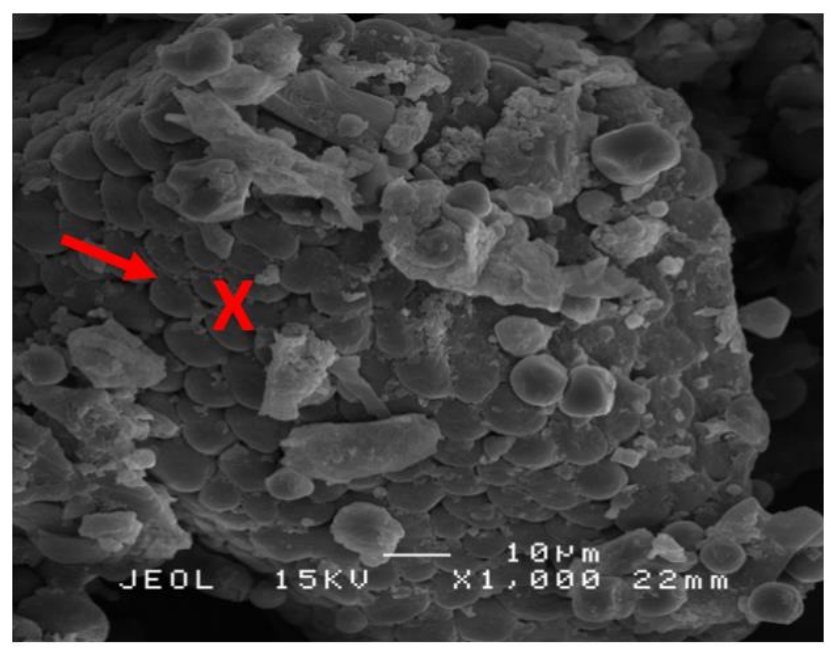

Plate 1 Oven dried millet flour from dehulled millet soaked in $1 \%$ citric acid $\times 1000$

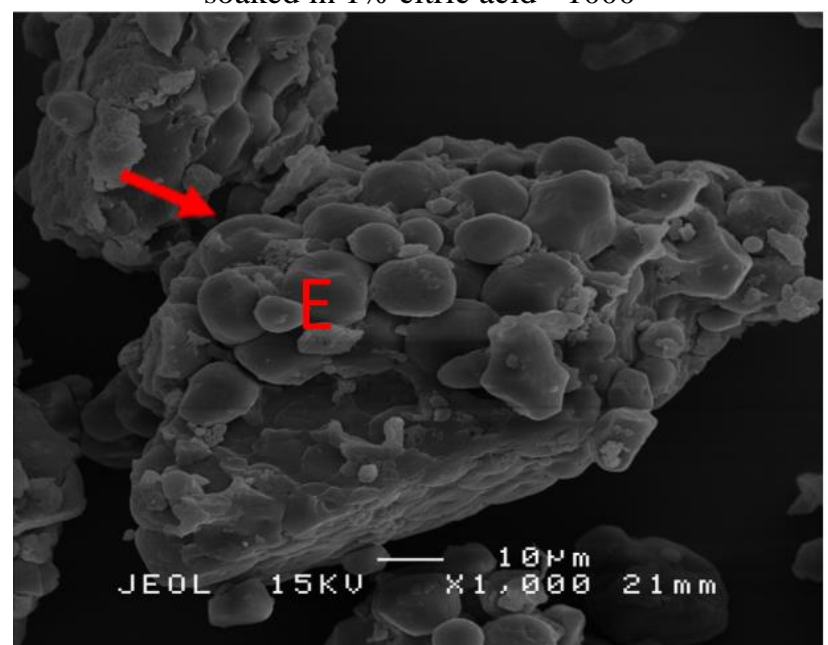

Plate 2 Oven dried millet flour from dehulled millet soaked in $1 \% \mathrm{Na}_{2} \mathrm{CO} 3 \times 1000$

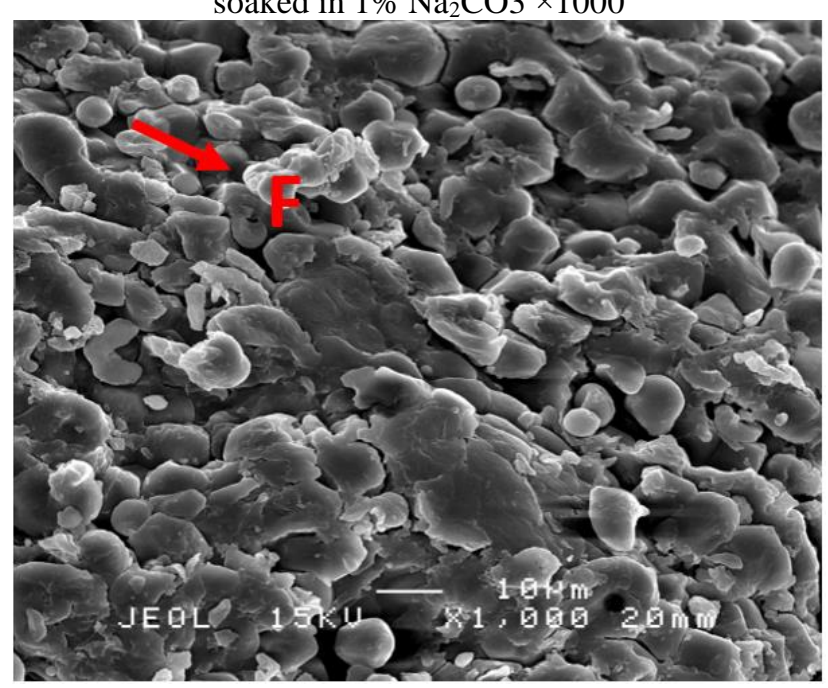

Plate 3 Oven dried millet flour from dehulled millet soaked in $1 \% \mathrm{NaCl} \times 1000$
Gelatinization Properties of Oven Dried Millet Flour from Dehulled Millet Depigmented in Different Solutions

Table 2 shows the gelatinization properties of oven dried millet flour from dehulled millet depigmented in different solutions as monitored by Differential Scanning Calorimetry [DSC]

The onset (To), peak (Tp), end set temperatures of gelatinization for oven dried millet flour from undepigmented dehulled millet differed significantly $(\mathrm{P}<0.05)$ from those of the depigmented samples. The onset temperature of gelatinization for control sample (ODMF5) was $97.65^{\circ} \mathrm{C}$, while from those of the depigmented samples which ranged from $70.15^{\circ} \mathrm{C}$ for sample ODMF4 to $85.65^{\circ} \mathrm{C}$ for sample ODMF3. The higher To temperature observed in sample ODMF5 could be associated with inadequate uptake of water required for gelatinization to occur. This invariably suggests that the sample was not sufficiently hydrated thus the gelatinization temperature was affected.

The peak temperature of gelatinization (Tp) for control sample (ODMF5) was $102.31^{\circ} \mathrm{C}$, while from those of the depigmented samples ranged from $79.63^{\circ} \mathrm{C}$ (ODMF2) to $96.35^{\circ} \mathrm{C}$ (ODMF3). $\mathrm{Na}_{2} \mathrm{CO}_{3}$ affects the texture of foods by causing hardening, this effect may have enhanced the weakening of granules and caused the sudden collapse of starch structure thus resulting in the noticeable low peak temperature of gelatinization.

The highest end set temperature $\left(104.96^{\circ} \mathrm{C}\right)$ of gelatinization (Te) was observed in the control sample (ODMF5) while lowest Te value was observed in sample ODMF2. Samples ODMF2 $\left(83.30^{\circ} \mathrm{C}\right)$ and ODMF4 $\left(84.23^{\circ} \mathrm{C}\right)$ had comparable Te values.

Oven dried millet flour from undepigmented dehulled millet (control) had an enthalpy $(\Delta \mathrm{H})$ value of $6.70 \mathrm{~J} / \mathrm{g}$ which differed significantly $(\mathrm{P}<0.05)$ from that of the depigmented samples which ranged from $7.44 \mathrm{~J} / \mathrm{g}$ (ODMF3) to $18.22 \mathrm{~J} / \mathrm{g}$ (ODMF1). Starch gelatinization is an order-disorder phase transition of starch granules in the presence of water and heat which results in loss of the crystalline order, swelling of granules and solubilization of starch molecules. This transition is endothermic and the heat change is called gelatinization enthalpy (Nwokocha and Williams, 2011).

Higher To, Tp, Te values were observed in the control sample (ODMF5) than in samples ODMF4, ODMF3 and ODMF2 probably due to the fact that there was no hydration so the starch granules did not imbibe enough water required for gelatinization to occur. High To, Tp, Te values were observed in the sample soaked in $1 \%$ $\mathrm{NaCl}$ (ODMF3). According to Ratnayake et al. (2009) $\mathrm{NaCl}$ exert a protective or restrictive effect on starch gelatinization which could reflect as high To, Tp, Te values. Chiotelli et al. (2002) and Day et al. (2013) reported that $\mathrm{NaCl}$ concentrations below $7 \%$ increases the temperature at which starch gelatinization occurs or begins, whereas high concentrations exert an opposite effect. Ratnayake et al. (2009) reported that both sodium chloride and sucrose increase starch gelatinization temperature and decrease the degree of gelatinization. According to Bonnet (1993), the amount of amylose in solution increase with increased concentrations of citric acid thus hastening granule disruption during gelatinization while with increased concentrations of 
sugar, amylose in solution decreases thus delaying granule disruption. Acid hydrolysis has been reported to increase the crystallinity of starch granules, this is attributed to the preferential breakdown of amorphous region of the granules (Wang et al., 2006). Starch gelatinization temperature range is a measure of the cooking quality of starch and it is an important parameter in food processing. Starches with low gelatinization temperature ranges are known to have good cooking quality (Waters et al., 2005). High gelatinization temperatures indicate higher stability of starch crystallites in starch molecules.

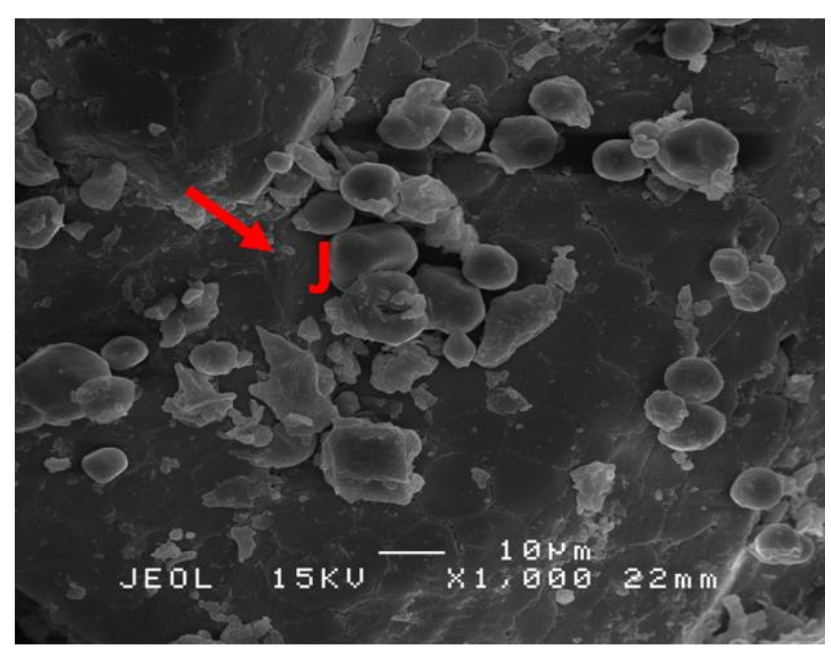

Plate 4 Oven dried millet flour from dehulled millet soaked in water $\times 1000$

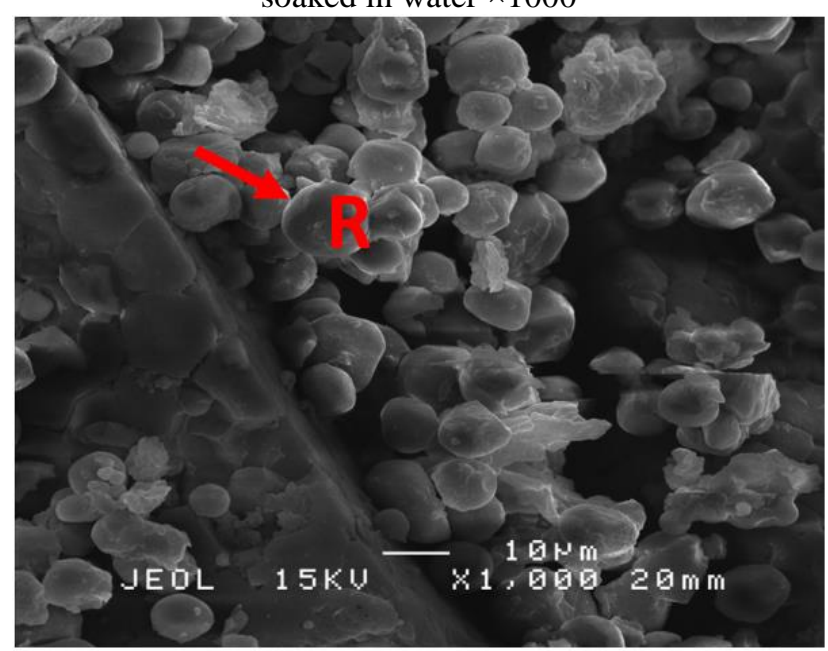

Plate 5 Oven dried millet flour from unsoaked dehulled millet (control) $\times 1000$

Chemical Composition of Depigmented Oven Dried Milllet Flour

Table 3 shows the chemical composition of depigmented oven dried millet flour. The moisture content of flour from undepigmented dehulled millet (control) was $10.19 \%$ and it differed significantly $(\mathrm{P}<0.05)$ from that of the depigmented samples, which ranged from 8.31 (ODMF4) to $10.88 \%$ (ODMF4). Oven dried millet flour from dehulled millet grain soaked in water had the highest moisture content $(10.88 \%)$, this may be a reflection of higher amount of water imbibed during soaking in the depigmentation process. The low moisture content observed for sample ODMF5 suggests that water was more easily removed during oven drying process because there hydration of the grain was inadequate due to the absence of soaking of the grain. The ether extract content of flour from undepigmented dehulled millet (control) was $4.49 \%$ while that of depigmented samples ranged from 4.27 (ODMF2) to $4.63 \%$ (ODMF4) showing no significant difference $(\mathrm{P}>0.05)$ in ether extract content of the control and depigmented samples. Ether extract contents of samples was not affected by the depigmentation process probably due to the fact that the germ was intact after dehulling by the traditional method (mortar and pestle) irrespective of soaking media. The ether extract of samples observed in this study agrees with the value $(4.80 \%)$ reported by Belton and Taylor (2004).

The total ash content of flour from dehulled undepigmented millet (control) was $1.00 \%$ while that of the depigmented samples ranged from 0.71 (ODMF1) to $1.19 \%$ (ODMF2). The observed high ash content of sample ODMF2 may depict minimal leaching losses when soaked in $1 \% \mathrm{Na}_{2} \mathrm{CO}_{3}$ compared to other soak solutions. The low total ash content recorded in this study compare with the values $(0.25$ to $2.54 \%)$ reported by Seghal and Kawatra, (2008). Karle and Beleia, (2010) reported that the removal of the outer layer of pearl millet accounted for mineral losses.

The undepigmented dehulled sample (control) showed a crude protein content of $8.55 \%$ while depigmented samples had crude protein content that ranged from $7.25 \%$ in sample ODMF1 to $8.67 \%$ in sample ODMF3. Though treatments caused variation in the crude protein content, samples ODMF3 and ODMF5 showed comparable crude protein content which differed significantly $(\mathrm{P}<0.05)$ from other samples. The high protein content $(8.67 \%)$ observed in sample ODMF3 could suggest that $\mathrm{NaCl}$ solution was stable, that is had equal number of $\mathrm{H}^{+}$and $\mathrm{OH}^{-}$ion, thus there was no leaching of protein into the soak solution. The percentage crude protein, fat, crude fiber and ash contents of pearl millet reported by various workers (Seghal and Kawatra, 2008) ranged from 7.02 to $13.67,4.02$ to $7.80,0.54$ to 3.00 and 0.25 to 2.54 , respectively. The variation in protein content values could be attributed to the effect of the soaking media ( $1 \%$ citric acid, $1 \% \mathrm{NaCO}_{3}$ and water) which may have enhanced leaching of soluble protein. Rathi et al. (2003) reported that low values of protein $(6.73 \%)$ in biscuits prepared from pearl millet depigmented with $0.2 \mathrm{~N} \mathrm{HCl}$ was partly due to hydrolysis and leaching of protein into soaking medium during depigmentation.

The $\mathrm{pH}$ of the control sample was 6.28 while that of the depigmented samples varied significantly $(\mathrm{P}<0.05)$ ranging from 4.35 in flour from dehulled millet grain soaked in $1 \%$ citric acid (ODMF1) to 8.45 in oven dried millet flour from dehulled millet grain soaked in $1 \%$ $\mathrm{Na}_{2} \mathrm{CO}_{3}$ (ODMF2). The $\mathrm{pH}$ of the soak solution of depigmented samples ranged from 3.32 (ODMF1) to 9.93 (ODMF2). There were significant differences $(\mathrm{P}<0.05)$ in $\mathrm{pH}$ of the soak solutions of the depigmented samples. Highest $\mathrm{pH}$ expectedly indicates the high concentration of $\mathrm{OH}^{-}$ion in media $\left(\mathrm{Na}_{2} \mathrm{CO}_{3}\right)$ an alkali while low $\mathrm{pH}$ depicts the high concentration of $\mathrm{H}^{+}$ions in acid $(1 \%$ citric acid). 
Table 2 Gelatinization temperatures of oven dried millet flour from dehulled millet depigmented in different solutions

\begin{tabular}{c|cccc}
\multicolumn{1}{c}{ Samples } & $\operatorname{To}\left({ }^{\circ} \mathrm{C}\right)$ & $\operatorname{Tp}\left({ }^{\circ} \mathrm{C}\right)$ & $\operatorname{Te}\left({ }^{\circ} \mathrm{C}\right)$ & $\Delta \mathrm{H}(\mathrm{J} / \mathrm{g})$ \\
\hline ODMF1 & $78.78^{\mathrm{cd}} \pm 1.56$ & $90.95^{\mathrm{c}} \pm 0.11$ & $96.52^{\mathrm{c}} \pm 0.06$ & $18.22^{\mathrm{a}} \pm 1.20$ \\
ODMF2 & $77.13^{\mathrm{d}} \pm 1.05$ & $79.48^{\mathrm{d}} \pm 0.00$ & $83.30^{\mathrm{d}} \pm 0.59$ & $15.17^{\mathrm{b}} \pm 1.34$ \\
ODMF3 & $85.65^{\mathrm{b}} \pm 0.44$ & $96.35^{\mathrm{b}} \pm 0.00$ & $101.76^{\mathrm{b}} \pm 0.01$ & $7.44^{\mathrm{d}} \pm 0.89$ \\
ODMF4 & $70.15^{\mathrm{e}} \pm 0.36$ & $79.63^{\mathrm{d}} \pm 0.50$ & $84.23^{\mathrm{d}} \pm 0.05$ & $10.81^{\mathrm{c}} \pm 0.49$ \\
ODMF5 & $97.65^{\mathrm{a}} \pm 0.39$ & $102.31^{\mathrm{a}} \pm 0.09$ & $104.96^{\mathrm{a}} \pm 0.00$ & $6.70^{\mathrm{d}} \pm 1.45$ \\
\hline
\end{tabular}

Values are means of triplicate determination \pm standard error mean (SEM). Means bearing the same superscript in the same column are not significantly different $(\mathrm{P}>0.05)$

Table 3: Effects of depigmentation treatments on the Chemical composition of oven dried millet flour

\begin{tabular}{|c|c|c|c|c|c|}
\hline Parameters & ODMF1 & ODMF2 & ODMF3 & ODMF4 & ODMF5 \\
\hline Moisture (\%) & $10.53^{\mathrm{ab}} \pm 0.21$ & $10.70^{\mathrm{ab}_{ \pm}} \pm 0.17$ & $10.43^{\mathrm{b}} \pm 0.24$ & $10.88^{\mathrm{a}} \pm 0.02$ & $10.19^{c} \pm 0.08$ \\
\hline Ether Extract (\%) & $4.45^{\mathrm{a}} \pm 0.01$ & $4.27^{\mathrm{a}} \pm 0.02$ & $4.43^{\mathrm{a}} \pm 0.11$ & $4.61^{\mathrm{a}} \pm 0.14$ & $4.49^{\mathrm{a}} \pm 0.05$ \\
\hline Total Ash (\%) & $0.71^{\mathrm{e}} \pm 0.01$ & $1.19^{\mathrm{a}} \pm 0.03$ & $0.86^{\mathrm{c}} \pm 0.05$ & $0.77^{\mathrm{de}} \pm 0.12$ & $1.00^{\mathrm{b}} \pm 0.08$ \\
\hline Crude Protein (\%) & $7.25^{\mathrm{c}} \pm 0.12$ & $7.53^{\mathrm{bc}} \pm 0.25$ & $8.67^{\mathrm{a}} \pm 0.04$ & $7.77^{b} \pm 0.14$ & $8.55^{\mathrm{a}} \pm 0.05$ \\
\hline Crude fiber $(\%)$ & $1.08^{\mathrm{a}} \pm 0.03$ & $1.00^{\mathrm{a}} \pm 0.01$ & $1.00^{\mathrm{a}} \pm 0.06$ & $1.07^{\mathrm{a}} \pm 0.05$ & $1.04^{\mathrm{a}} \pm 0.08$ \\
\hline $\mathrm{pH}$ & $4.35^{\mathrm{e}} \pm 0.01$ & $8.45^{\mathrm{a}} \pm 0.01$ & $6.08^{\mathrm{d}} \pm 0.01$ & $6.12^{c} \pm 0.01$ & $6.28^{\mathrm{b}} \pm 0.00$ \\
\hline Total titratable acidity (TTA) & $0.084^{\mathrm{a}} \pm 0.01$ & $0.001^{\mathrm{d}_{ \pm}} 0.00$ & $0.036^{\mathrm{b}} \pm 0.00$ & $0.027^{\mathrm{c}} \pm 0.00$ & $0.039^{\mathrm{b}} \pm 0.00$ \\
\hline $\mathrm{pH}$ of soak solution & $3.32^{\mathrm{d}} \pm 0.00$ & $9.93^{\mathrm{a}} \pm 0.05$ & $5.45^{\mathrm{b}} \pm 0.00$ & $5.30^{c} \pm 0.00$ & NA \\
\hline Phytates $(\mathrm{mg} / 100 \mathrm{~g})$ & $2.56^{\mathrm{b}} \pm 0.01$ & $1.84^{\mathrm{a}} \pm 0.01$ & $3.31^{\mathrm{cd}_{ \pm}} 0.02$ & $5.13^{\mathrm{d}} \pm 0.03$ & $6.45^{\mathrm{e}} \pm 0.04$ \\
\hline Tannins $(\mathrm{mg} / 100 \mathrm{~g})$ & $3.77^{c} \pm 0.07$ & $3.06^{\mathrm{a}} \pm 0.05$ & $3.43^{b} \pm 0.04$ & $5.48^{\mathrm{d}} \pm 0.04$ & $6.68^{\mathrm{e}_{ \pm}} \pm 0.01$ \\
\hline $\mathrm{Na}(\mathrm{mg} / 100 \mathrm{~g})$ & $40.50^{e} \pm 0.15$ & $72.00^{c} \pm 0.10$ & $76.50^{\mathrm{b}} \pm 0.15$ & $83.50^{\mathrm{a}} \pm 0.15$ & $65.50^{\mathrm{d}} \pm 0.15$ \\
\hline $\mathrm{K}(\mathrm{mg} / 100 \mathrm{~g})$ & $127.50^{\mathrm{e}} \pm 0.15$ & $168.00^{\mathrm{c}} \pm 0.10$ & $199.50^{\mathrm{a}} \pm 0.10$ & $193.50^{b} \pm 0.15$ & $160.50^{\mathrm{d}_{ \pm}} \pm 0.15$ \\
\hline $\mathrm{P}(\mathrm{mg} / 100 \mathrm{~g})$ & $188.00^{\mathrm{e}} \pm 0.10$ & $275.00^{c} \pm 0.10$ & $284.00^{\mathrm{b}} \pm 0.10$ & $305.00^{\mathrm{a}} \pm 0.10$ & $262.50^{\mathrm{d}} \pm 0.15$ \\
\hline $\operatorname{Mg}(\mathrm{mg} / 100 \mathrm{~g})$ & $286.00^{\mathrm{e}} \pm 0.01$ & $466.00^{\mathrm{c}} \pm 0.01$ & $474.00^{\mathrm{b}} \pm 0.01$ & $533.00^{\mathrm{a}} \pm 0.01$ & $364.00^{\mathrm{d}} \pm 0.10$ \\
\hline $\mathrm{Ca}(\mathrm{mg} / 100 \mathrm{~g})$ & $109.50^{f} \pm 0.15$ & $268.00^{\mathrm{c}} \pm 0.10$ & $290.00^{b} \pm 0.10$ & $316.50^{\mathrm{a}} \pm 0.15$ & $205.0^{\mathrm{e}} \pm 0.10$ \\
\hline $\mathrm{Fe}(\mathrm{mg} 100 / \mathrm{g})$ & $1.48^{\mathrm{ab}} \pm 0.03$ & $1.46^{\mathrm{ab}} \pm 0.10$ & $1.54^{\mathrm{ab}} \pm 0.00$ & $1.75^{\mathrm{a}} \pm 0.00$ & $1.32^{b c} \pm 0.00$ \\
\hline $\mathrm{Zn}(\mathrm{mg} / 100 \mathrm{~g})$ & $2.19^{\mathrm{e}} \pm 0.15$ & $2.77^{c} \pm 0.10$ & $2.94^{\mathrm{b}} \pm 0.00$ & $3.14^{\mathrm{a}} \pm 0.00$ & $2.65^{\mathrm{d}} \pm 0.00$ \\
\hline $\mathrm{I}(\mathrm{mg} / 100 \mathrm{~g})$ & $0.12^{f_{ \pm}} \pm 0.15$ & $0.27^{\mathrm{c}} \pm 0.00$ & $0.29^{b} \pm 0.00$ & $0.31^{\mathrm{a}} \pm 0.00$ & $0.20^{\mathrm{d}_{ \pm}} \pm 0.00$ \\
\hline
\end{tabular}

The phytate and tannin contents of control sample (ODMF5) was $6.45 \mathrm{mg} / 100 \mathrm{~g}$ and $6.68 \mathrm{mg} / 100 \mathrm{~g}$, respectively while that of depigmented samples ranged from $1.84 \mathrm{mg} / 100 \mathrm{~g}$ (ODMF2) to $5.13 \mathrm{mg} / 100 \mathrm{~g}$ (ODMF4) and $3.06(\mathrm{ODMF} 2)$ to $5.80 \mathrm{mg} / 100 \mathrm{~g}$, respectively. There were significant differences $(\mathrm{P}<0.05)$ between phytate and tannin contents of the control and the depigmented samples. It was observed in this study that the phytate and tannin contents of samples were generally low when compared to reports of previous studies (El- Maki et al., 2007; Mohammed et al., 2011), this could be attributed to the effect of initial dehulling prior to soaking. Also, samples soaked in $1 \%$ citric acid solution showed significantly $(\mathrm{P}<0.05)$ reduced levels of phytates and tannins than those soaked in water and the undepigmented dehulled sample (ODMF5). Similarly, soaking in $1 \%$ $\mathrm{Na}_{2} \mathrm{CO}_{3}$ significantly $(\mathrm{P}<0.05)$ reduced the levels of phytates and tannins, a similar trend was reported by Towo et al. (2003), who observed that soaking in alkali $\left(\mathrm{NaHCO}_{3}, \mathrm{pH} 8.4\right)$ and acidic media (lactic acid, $\mathrm{pH} 3$ ) were effective in reducing total amount of extractable phenolics in sorghum and millet. Reichert, (1979) also reported that depigmentation of pearl millet with acidic medium was most effective.

It was observed that sample (ODMF1) depigmented in $1 \%$ citric acid solution had lower mineral contents $(\mathrm{Na}, \mathrm{K}$, $\mathrm{P}, \mathrm{Mg}, \mathrm{Ca}, \mathrm{Zn}$ and I) than the control sample (ODMF5) and other samples (ODMF2, ODMF3 and ODMF4) depigmented in other solution. This could be due to the increased concentration of $\mathrm{H}^{+}$ions in the citric acid solution that may have affected the leaching of minerals as the $\mathrm{pH}$ of sample was 4.35. Saleh et al. (2013) reported that mineral contents especially $\mathrm{P}, \mathrm{Ca}$ and $\mathrm{Fe}$ were reduced with increased period of soaking pearl millet in acid and attributed it to leaching out of the minerals into the soaking solution.

\section{Conclusion}

The study has been able to establish that oven dried depigmented millet flours were produced by soaking dehulled millet in different solutions. Depigmenting dehulled millet by soaking in $1 \% \mathrm{Na}_{2} \mathrm{CO}_{3}$ impaired the colour of sample ODMF2 while depigmenting dehulled millet grains by soaking in $1 \%$ citric acid solution for $12 \mathrm{~h}$ improved colour of sample ODMF1. Higher To, Tp and Te (onset, peak and end set gelatinization temperatures) values were observed for undepigmented oven dried millet flour (ODMF5) compared to depigmented samples (ODMF1, ODMF2, ODMF3 and ODMF4). The pH of soaking solutions influenced the chemical composition of oven dried millet flours. Phytate content of sample ODMF2 decreased when dehulled millet was soaked in $1 \% \mathrm{Na}_{2} \mathrm{CO}_{3}$ for $12 \mathrm{~h}$. The method most preferred for ODMF involves depigmenting dehulled millet grains by soaking in $1 \%$ citric acid solution.

Oven dried millet flours can be used in producing thick porridges such as 'tuwo' in accompaniment with soup or thin porridges (gruels) are usually taken for breakfast. 


\section{References}

Adebowale KO, Afolabi TA and Olu-Owolabi BI. 2005. Hydrothermal treatments of finger millets (Eleusine coracana) starch. Food Hydrocolloids, 19: 974-983.

AOAC. 2012. Official methods of Analysis. Association of Official Analytical Chemists. Washington DC. 18th ed.

Belton PS and Taylor JRN. (2004). Sorhgum and millets: protein sources for Africa. Trends in Food Science and Technology, 15: $94-98$.

Bonnet F. 1993. Technological treatments of cereals. Repercussions on the physiological properties of starch. Carbohydrate Polymers, 21: 195-203.

Chiotelli E, Pilosio G and Le Meste M. 2002. Effect of sodium chloride on the gelatinization of starch: a multi measurement study. Biopolymers, 63(1): 41-58.

Day L, Fayet $\mathrm{C}$ and Homer S. 2013. Effect of $\mathrm{NaCl}$ on the thermal behavior of wheat starch in excess and limited water. Carbohydrate polymers, 94: 31- 37.

El- Maki HB, Abdel-Rahman, SM, Idris WH, Hassan AB, Babiker EE, El- tinay AH. 2007. Content of antinutritional factors and $\mathrm{HCl}$ extractability of mineral from white beans (Phaseolus vulgaris) cultivars; influence of soaking and/or cooking. Food Chemistry, 100: 362-368.

Kadam SS, Salunkhe DK. 1989. Nutritional composition, processing and utilization of horse gram and moth beans. Critical Review of Food Science and Nutrition, 22(1): 1-26.

Karle ENL, Beleia A. 2010. Effect of soaking and cooking on phytate concentration, minerals, and texture of food-type soybeans. Cienc. Tecnol. Aliment Campinas, 30(4): 10561060.

Latta M, Eskin M. 1980. A simple and rapid colorimetric method for phytate determination. Journal of Agricultural Food Chemistry, 28: 1213-1215.

Mohammed RK, Abou-Arab EA, Giberiel AY, Rasmy NMH and Abu-Salem FM. 2011. Effect of legume processing treatments individually or in combination on their phytic acid content. African Journal of Food Science and Technology, 2(2): 36-46.

Nielsen SS. 2002. Introduction to the Chemical analysis of Foods. CSB Publishers. New Delhi, India. Pp 181-258.

Nwokocha LM, Williams PA. 2011. Structure and properties of Treculia africana (Decne) seed starch. Carbohydrate polymers, 84: 395-401.

Onwuka GI. 2005. Food analysis and instrumentation, theory and practice. Napthali Prints, Lagos. Pp.104-120.

Pearson D. 1976. The Chemical analysis of Foods. 7th ed. Churchill Livingstone, Edinburgh. Pp 494-497.

Pelissari FM, Andrade-Mahecha MM, Sobral PJ, Menegali FC. 2012. Isolation and characterization of the flour and starch of plantain banana (Musa paradisiaca). Starch, 64: 382-391. DOI 10.1002/star.201100133.accessed on 30/7/2013.
Rathi A, Kawatra A, Seghal S and Housewright B. 2003. Influence of depigmentation of pearl millet (Pennisetum glaucum L.) on sensory attributes, nutrient composition and invitro digestibility of biscuits. Lebensm-Wiss-u-Technol, 37: 187- 192 .

Ratnayake WS, Otani C and Jackson DS. 2009. DSC enthalpic transitions during starch gelatinization in excess water, dilute sodium chloride and dilute sucrose solutions. Journal of the Science of Food and Agriculture, 89 (12): 2156-2164.

Reichert RD. 1979. The $\mathrm{pH}$ sensitive pigments in pearl millet. Cereal Chemistry, 56(4): 291-294.

Saleh ASM, Zhang Q, Chen J and Shen Q. 2013. Millet grains: Nutritional Quality, Processing and Potential Health Benefits. Comphrensive Reviews in Food Science and Technology,; 12: $281-295$.

Shahidi F, Chandrasekara A. 2013. Millet grain phenolics and their role in disease risk reduction and health promotion: A review. Journal of Functional Foods 5: 570-581.

Seghal AS, Kawatra A. 2008. Development and nutritional evaluation of pearl millet rich banana cake. Journal of Dairying, Foods and Home Sciences, 27(2): 138-141.

Shobana S, Malleshi NG. 2007. Preparation and functional properties of decorticated finger millet (Eleusine corocana). Journal of Food Engineering, 79: 529-538.

Suma PF, Urooj A. 2011. Nutrients, antinutrients and bioaccessible mineral content (invitro) of pearl millet as influenced by milling. Journal of Food Science and Technology, 51(4): 756-761. DOI 110.1007/s13197-011$0541-7$ accessed on 27/6/2013.

Towo EE, Svanberg U, Ndossi GD. 2003. Effect of grain pretreatment on different extractable phenolic groups in cereals and legumes commonly consumed in Tanzania. Journal of Science Food Agriculture, 83: 980 - 986 DOI:10.1002/jsfa.1435.

Vaintraub IA, Lapteva NA. 1988. Colorimetric determination of phytate in unpurified extracts of seeds and products of their processing. Analytical Biochemistry, 17: 227-230.

Wang SJ, Gao WY, Yu JL, Xiao PG. 2006. The Crystalline changes of starch from Rhizoma discorea by acid hydrolysis. Chinese Chemical Letters, 17(9): 1255-1258.

Wanjekeche E, Wakasa V, Mureithi JG. 2003. Effect of germination, alkaline and acid soaking and boiling on the nutritional value of mature and immature Mucuna (Mucuna pruriens) beans. Tropicana and Subtropical Agroecosystems, 1: $183-192$.

Waters DLE, Henry RJ, Reinke RF and Fitzgerald MA. 2005. Gelatinization temperature of rice explained by polymorphisms in starch synthase. Plant Biotechnology Journal, 4(1): 115-122 